\title{
PREOPERATIVE ELECTROCARDIOGRAPHIC STUDY OF DOGS AT THE VETERINARY HOSPITAL OF PONTIFÍCIA UNIVERSIDADE CATÓLICA DO PARANÁ
}

\author{
ESTUDO ELETROCARDIOGRÁFICO PRÉ-OPERATÓRIO DE CÃES \\ ATENDIDOS NO HOSPITAL VETERINÁRIO DA PONTIFÍCIA \\ UNIVERSIDADE CATÓLICA DO PARANÁ
}

\author{
Solimar Dutra Silveira ${ }^{*}$ \\ Bruna Gabriela Gheller ${ }^{1}$ \\ Andréa Christina Ferreira Meirelles ${ }^{1}$ \\ ${ }^{1}$ Pontifícia Universidade Católica do Paraná - PUCPR, Toledo, PR, Brasil. \\ "Corresponding author - solimards@hotmail.com
}

\begin{abstract}
Electrocardiogram is considered a substantial instrument in the clinical evaluation of patients with heart disease. This tool can be used to determine the origin and frequency of the impulse as well as the cardiac conduction disorders. The aim of this study was to evaluate the frequency and type of electrocardiographic abnormalities in the immediate preoperative period of 60 dogs seen in the surgery department of the Veterinary Hospital of Pontifícia Universidade Católica do Paraná PUCPR, campus Toledo, between September 2015 and June 2017, and to analyze its correlation with the different breeds, sex, age, and weight of each patient. Alterations in the preoperative electrocardiogram have been shown to be frequent and their occurrence is independent of age, breed, size, and sex of the animal. The most frequent findings in the present study were the following: respiratory sinus arrhythmia (30\%), atrial fibrillation (16,7\%), sinus tachycardia (10\%), increase in $\mathrm{R}$ wave amplitude (10\%), and ST segment depression (10\%). Therefore, electrocardiography proved to be an auxiliary diagnostic method of great relevance in the dogs' preoperative period, guaranteeing greater anesthesia safety and lower risks of cardiovascular complications.
\end{abstract}

Keywords: anesthetic safety; cardiac conduction; electrocardiogram.

\section{Resumo}

A eletrocardiografia é considerada um instrumento substancial na avaliação clínica de pacientes cardiopatas, sendo possível por meio dela, determinar a origem e a frequência do impulso, bem como os distúrbios de condução cardíaca. Objetivou-se com o presente estudo avaliar a frequência e o tipo de anormalidades eletrocardiográficas existentes no pré-operatório imediato de 60 cães atendidos no departamento de cirurgia do Hospital Veterinário da Pontifícia Universidade Católica do Paraná PUCPR, campus Toledo, entre setembro de 2015 e junho de 2017, e analisar a sua correlação com as diferentes raças, sexo, idade e peso de cada paciente. Constatou-se que as alterações no eletrocardiograma pré-operatório são frequentes e sua ocorrência é independente de idade, raça, porte e sexo do animal. Os achados mais frequentes no presente estudo foram os seguintes: arritmia sinusal respiratória $(30 \%)$, fibrilação atrial $(16,7 \%)$, taquicardia sinusal $(10 \%)$, aumento na amplitude da onda R (10\%) e infradesnivelamento de segmento ST (10\%). Desta maneira, a eletrocardiografia 
mostrou-se como um método diagnóstico auxiliar de suma relevância no pré-operatório de cães, garantindo maior segurança anestésica e menores riscos de complicações cardiovasculares.

Palavras-chave: condução cardíaca; eletrocardiograma; segurança anestésica.

Received on: August 29th, 2017.

Accepted on: November 30th, 2017

\section{Introduction}

The electrocardiogram (ECG) is considered an essential instrument in the clinical evaluation of patients with heart disease. Impulse origin and frequency and conduction disorders can be determined through this test. In addition, the examination provides information on the size of the cardiac chambers, changes in electrolytes (calcium and potassium), myocardial oxygenation status, and mainly arrhythmias. The ECG is part of check-up exams, especially in elderly animals, but it is also performed in some patients before procedures that require sedation or that involve general anesthesia $^{(1)}$.

Pre-surgery evaluations are a set of procedures and examinations performed in the period before surgery ${ }^{(2)}$, having as main aim to reduce mortality and surgical morbidity ${ }^{(3,4)}$. Tudury and colleagues $^{(5)}$ cite the possible occurrence of disturbs in rhythm, frequency, and/or cardiac functioning during the surgical procedures of dogs and cats as a result of the patient's own pathophysiological state, plus the side effects caused by anesthetic drugs. A good pre-surgical evaluation can, therefore, minimize the risks of surgical complications; however, even if properly performed, it does not guarantee the absence of complications ${ }^{(6)}$.

Rabelo $^{(7)}$ points out the great importance of the electrocardiographic examination as a preanesthetic evaluation of dogs and cats because it has the ability to reveal significant cardiovascular alterations that are not apparent to clinical examination. In this study, the electrocardiographic evaluation was performed as a preoperative examination of 32 asymptomatic dogs during physical examination of the cardiovascular system. Of these patients, $64.7 \%$ showed electrocardiographic alterations.

In general, preoperative electrocardiography should be performed in animals whose clinical and historical examination suggest some cardiopathy and also in those older than six years ${ }^{(3)}$. The heart of the elderly dog is prone to atrial fibrillation ${ }^{(8)}$, and the incidence of asymptomatic arrhythmias and valve insufficiency is high in dogs over 7 years old ${ }^{(9)}$.

Arrhythmias are defined as disorders caused by changes in the formation and/or conduction of the electrical impulse through the myocardial tissue. They can modify the origin and/or physiological diffusion of the electrical stimulus of the heart. Therefore, the electrocardiogram is the method of choice to study and diagnose these disorders ${ }^{(10-12)}$. Tudury et al. ${ }^{(5)}$ reported the occurrence of rhythm, frequency and/or cardiac functioning disorders during surgical procedures in dogs and cats. The electrocardiographic verification of changes in the cardiac rhythm in pre-anesthetic evaluation allows veterinarians to choose an anesthetic with lower arrhythmogenic potential, which makes the electrocardiographic examination a tool of great importance in the preoperative evaluation ${ }^{(7,13)}$.

There are several cardiac pathologies that culminate in the development of arrhythmias, being the degenerative valve disease the most common cardiopathy in $\operatorname{dog} \mathrm{s}^{(14)}$. A physiologically normal heart may present lethal arrhythmias in a variety of disorders, and abnormal electrocardiograms may be 
seen in animals with systemic disease, including electrolyte imbalances (hyperkalemia, hyponatremia, hypercalcemia, and hypocalcemia), neoplasias (especially splenic), gastric dilatationvolvulus syndrome, and sepsis ${ }^{(15,16)}$. The information obtained by the ECG is essential not only to determine the type, origin, and severity of cardiac arrhythmias but also to direct the treatment ${ }^{(17,18)}$.

The presence of a heart disease does not contraindicate a surgical procedure, but it is an important point to be considered in the decision to perform it and in the determination of an ideal anesthetic protocol $^{(9)}$. In this case, electrocardiography represents a fast and efficient way to obtain reliable parameters about the general and cardiovascular status of the patient ${ }^{(19)}$. During surgical procedures in dogs, the occurrence of frequency, rhythm and/or cardiac functioning disorders is possible due to the patient's own organic state, besides the effects caused by the drugs administered for anesthesia ${ }^{(5)}$. Given that certain arrhythmias increase anesthetic risks, a good preoperative ECG evaluation can minimize the risks of surgical complications, ensuring the success of anesthesia, and minimizing postoperative complications ${ }^{(6)}$.

The aim of this study was to evaluate the frequency and type of electrocardiographic abnormalities found during preoperative examination of dogs, relating it with the presence of surgical disease, obesity, age, sex, and weight of the animal.

\section{Material and Methods}

This study was previously approved by the Ethics Committee on the Use of Animals CEUA/PUCPR under the protocol 0955A/15.

Sixty dogs from the metropolitan and rural regions of Toledo, state of Paraná, were randomly assessed and directed to the surgery department of the Veterinary Hospital of PUCPR Campus Toledo, from September 2015 to June 2017.

Initially, the evaluation comprised data referring to the physical characteristics of the animal (race, age, weight, sex), followed by anamnesis, in order to obtain information about the cardiovascular function and the general condition of the patient, besides the surgical disease. After that, the general physical examination was continued. Anamnesis and general physical examination were performed according to the recommended literature ${ }^{(20)}$.

Subsequently, the electrocardiogram was performed with the standardized equipment with a sensitivity of $1 \mathrm{~cm}$ for each millivolt $(\mathrm{mV})$ and a recording rate of $50 \mathrm{~mm} / \mathrm{s}$ in the bipolar and unipolar leads on the limbs, with the animal positioned on right lateral decubitus with the limbs perpendicular to the body and parallel to each other. We used an electrocardiograph model C10 (Brazilian Electronic Technology - TEB) that can record by conventional and computerized methods.

The records of the electrocardiographic tracings in the present study were obtained by the conventional method on thermal paper suitable for the examination. Three complexes of each derivation and a 50-cm strip of derivation II were recorded by the conventional method ${ }^{(21)}$.

The alligator-type electrodes with loosened springs and fine-tuned teeth were clipped to the skin folds above the olecranon (palmar surface) on the left and right thoracic limbs and dorsally to the patellar ligaments (inguinal fold) on the left and right pelvic limbs, moistened with isoelectric gel for electrocardiogram to obtain the graphic record ${ }^{(16)}$. 
The frequency and heart rate, duration (in milliseconds-ms) of the $\mathrm{P}$ wave, the QRS complex, and the PR and QT intervals were verified by both methods. Amplitudes $(\mathrm{mV})$ of the P, R, and T waves, T wave polarity, ST segment leveling, and average electric spindle ${ }^{(16)}$, whose report was based on the evaluation of 3 to 4 complexes, were also verified. Moreover, the weight of the animals was taken into account for the interpretation of the duration and amplitude of the waves and the heart rate, as well as the age for the evaluation of the latter ${ }^{(21)}$.

The electrocardiogram was considered with alteration according to the definition by Carr et al. ${ }^{(10)}$ and Ramirez et al. ${ }^{(11)}$ for arrhythmia, following the analysis and values of duration (ms), amplitude (mV), and heart rate established by Tilley ${ }^{(21)}$ for the conventional method.

In the study of the surgical indication, the population was divided into two groups. In one group, the animals had an indication for elective surgery, which included procedures of ovariosalpingohisterectomy, orchiectomy, and periodontal prophylaxis in clinically healthy animals. In the other group, the animals had surgical indications related to other diseases, such as neoplasias, bone fractures, hernias, etc., called various surgeries. For this group, an evaluation of each surgical indication was later performed to verify a possible predisposition for the development of correlated arrhythmias.

To verify the frequency of electrocardiographic alterations according to weight, the animals were classified into three categories: up to $9.9 \mathrm{~kg}$, from 10.0 to $20.0 \mathrm{~kg}$ and above $20 \mathrm{~kg}$, following the standards established by Wolf et al. ${ }^{(22)}$. Once the age range of puppies, adults, and elderly dogs varies according to the size of the animal, a division was made to relate the two variables: the first group included small animals (up to $10 \mathrm{~kg}$ ), aged between seven and 10 months (puppies), 11 months to 8 years (adults), and over 8 years (elderly); the second group included medium-sized animals (11 to $25 \mathrm{~kg}$ ), whose age group was considered from seven to 11 months (puppies), from one year to seven years (adults), and older than seven years old (elderly); the last group corresponded to large dogs (weighing more than $25 \mathrm{~kg}$ ), whose age range was seven to 18 months (puppies), 19 months to five years (adults), and over five years (elderly) according to the literature classification ${ }^{(23)}$.

The descriptive analysis was performed relating the frequencies of the different variables: race, age, sex, and weight of the animal with the presence or absence of changes in the electrocardiogram for the general population.

\section{Results}

From de 60 dogs assessed in the present study, 23,3\% did not show any electrocardiographic alterations. Among the patients with a cardiac conduction disorder (76.7\%), the main findings were as follows: respiratory sinus arrhythmia (30\%, Figure 1), atrial fibrillation (16.7\%, Figure 2), sinus tachycardia (10\%, Figure 3), increase in R wave amplitude (10\%, Figures 2 and 4), and ST segment depression (10\%, Figures 1 and 4). Regarding the disorders found in lower frequencies, we observed: first-degree atrioventricular block (6.7\%), increase in P wave amplitude (3.3\%), decrease in $\mathrm{R}$ wave amplitude (3.3\%), ST segment elevation (3.3\%), and sinus bradycardia (3.3\%). These changes are presented in Figure 5. 


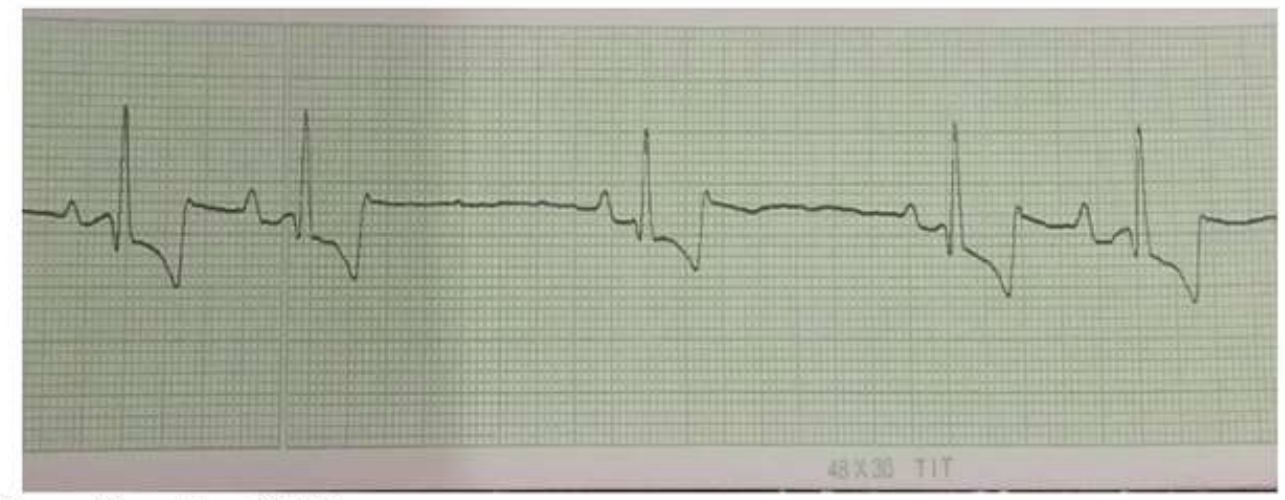

Source: The authors (2017).

Figure 1. Eleven-year-old male canine, cocker spaniel breed, body mass of $13.2 \mathrm{~kg}$, whose surgical pathology reported unilateral otohematoma. In the preoperative electrocardiographic tracing, there were changes compatible with respiratory sinus arrhythmia associated with ST segment depression.

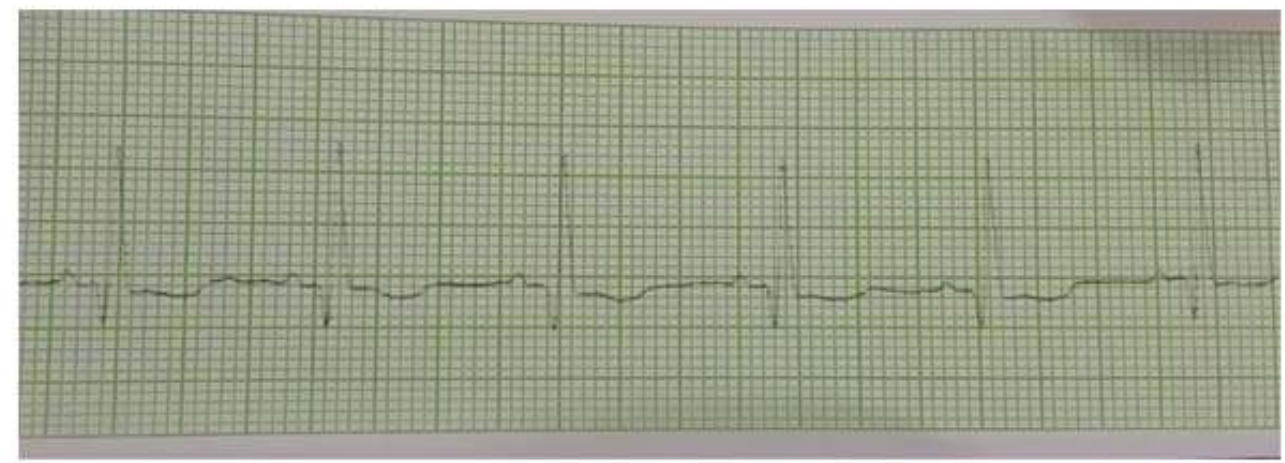

Source: The authors (2017).

Figure 2. Four-year-old male canine, French bulldog breed, corporal mass of $5.2 \mathrm{~kg}$, whose surgical pathology was related to the third unilateral eyelid gland prolapse. In the preoperative electrocardiographic tracing, changes compatible with atrial fibrillation associated with an increase in the amplitude of the $\mathrm{R}$ wave were evidenced.

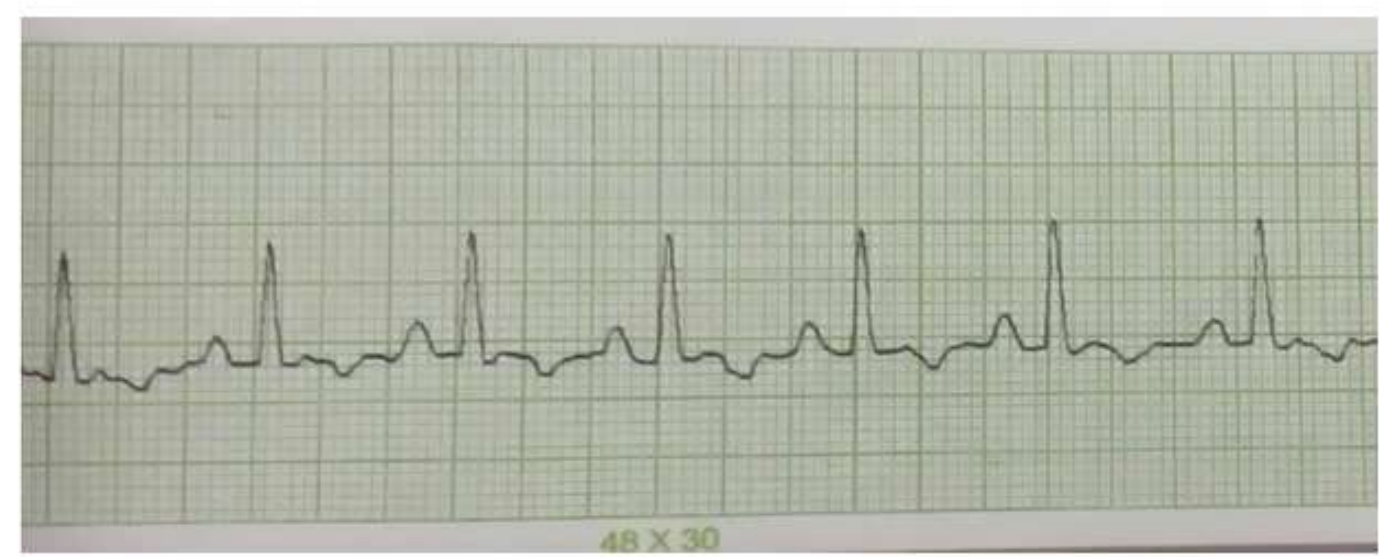

Source: The authors (2017)

Figure 3. Six-year-old female canine, with no defined breed, a body mass of $6.3 \mathrm{~kg}$, whose surgical pathology reported bone fracture in the distal portion of the right thoracic limb. In the preoperative electrocardiographic tracing, changes compatible with sinus tachycardia were observed. 


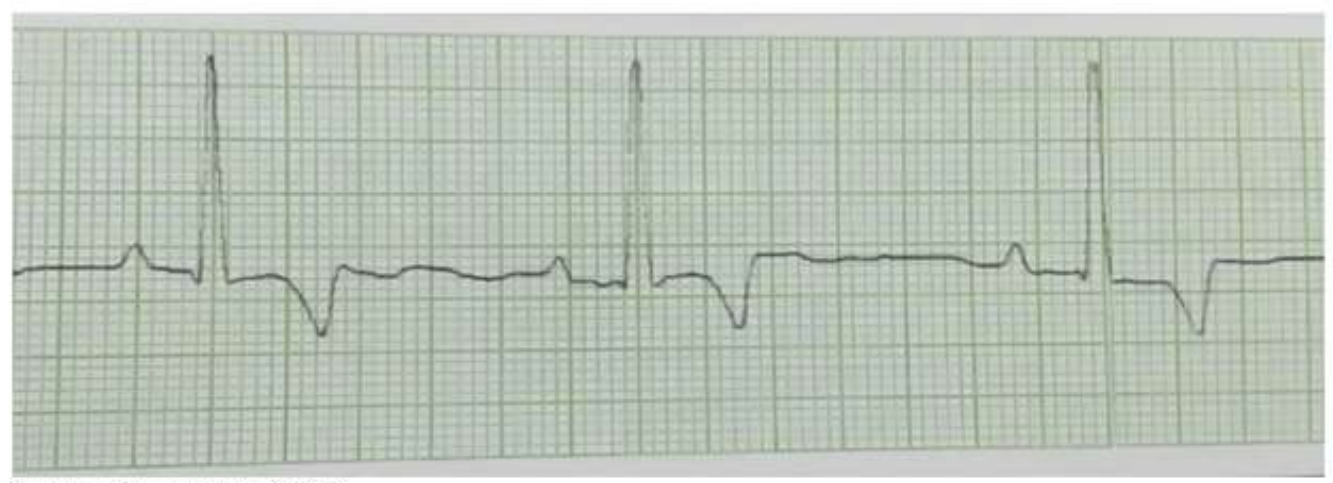

Source: The authors (2017).

Figure 4. Nine-year-old female canine, with no defined breed, a body mass of $17 \mathrm{~kg}$, whose surgical pathology was related to cystic endometrial hyperplasia. In the preoperative electrocardiographic tracing, changes compatible with increased $\mathrm{R}$ wave amplitude associated with ST segment depression were evidenced.

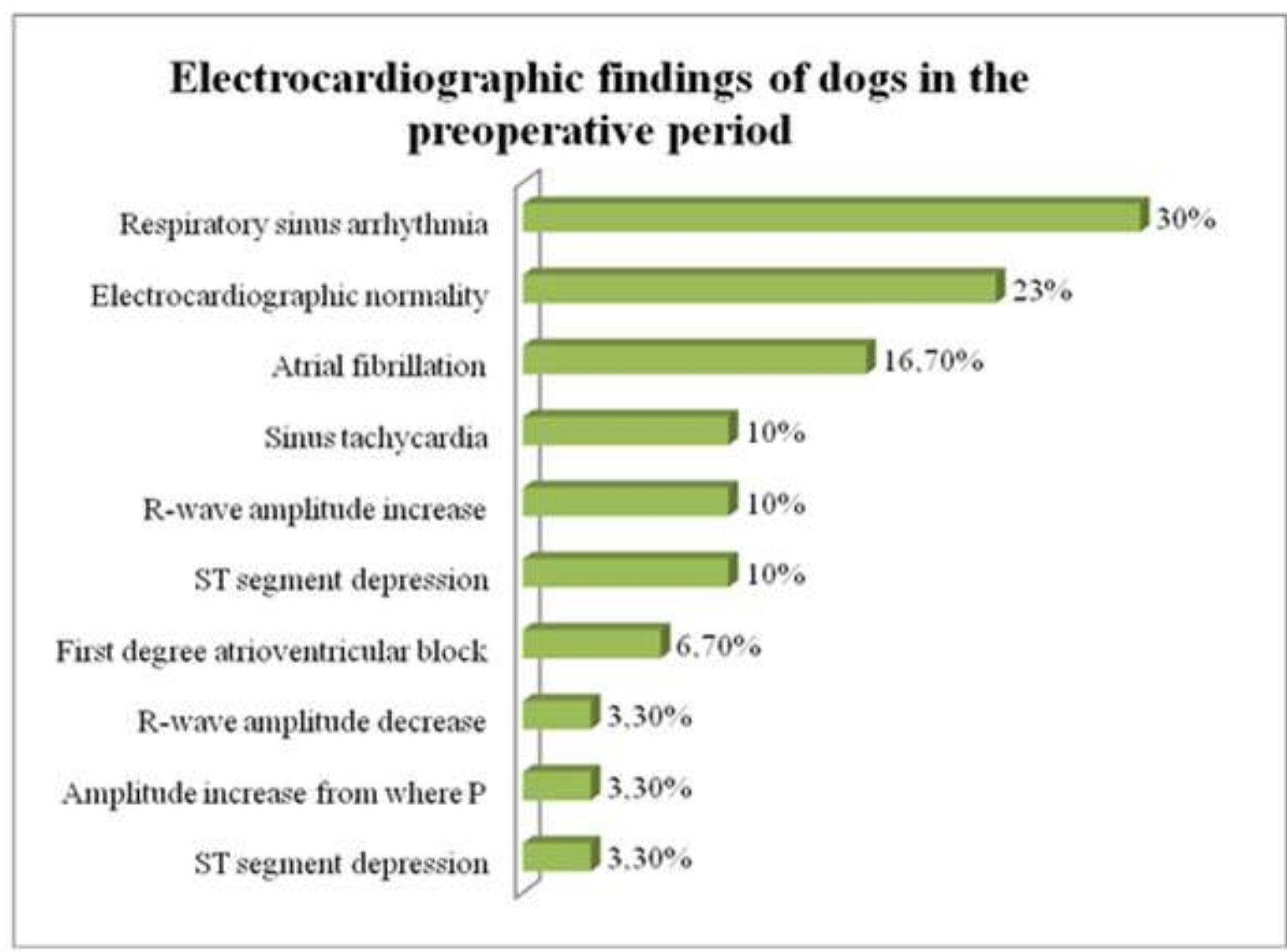

Source: The authors (2017).

Note: Some of the patients had more than one electrocardiographic change.

Figure 5. Electrocardiographic findings in the preoperative period of 60 dogs seen in the surgery sector of the Veterinary Hospital of PUCPR, campus Toledo.

As for the surgical conditions associated with each patient, the most prevalent diseases were: orthopedic conditions (20\%), breast neoplasias (13.3\%), and cystic endometrial hyperplasia (10\%). In the group corresponding to the elective procedures, the most common procedures were 
ovariosalpingohisterectomy - OSH (20\%), orchiectomy (6.7\%), and periodontal prophylaxis (3.3\%). By means of statistical analysis of all cases, we did not observe any predisposition to the development of cardiac conduction disorders that correlates with each pathology presented by the evaluated dogs. All elective procedures and surgical pathologies corresponding to the patients of this study are displayed in Figure 6.

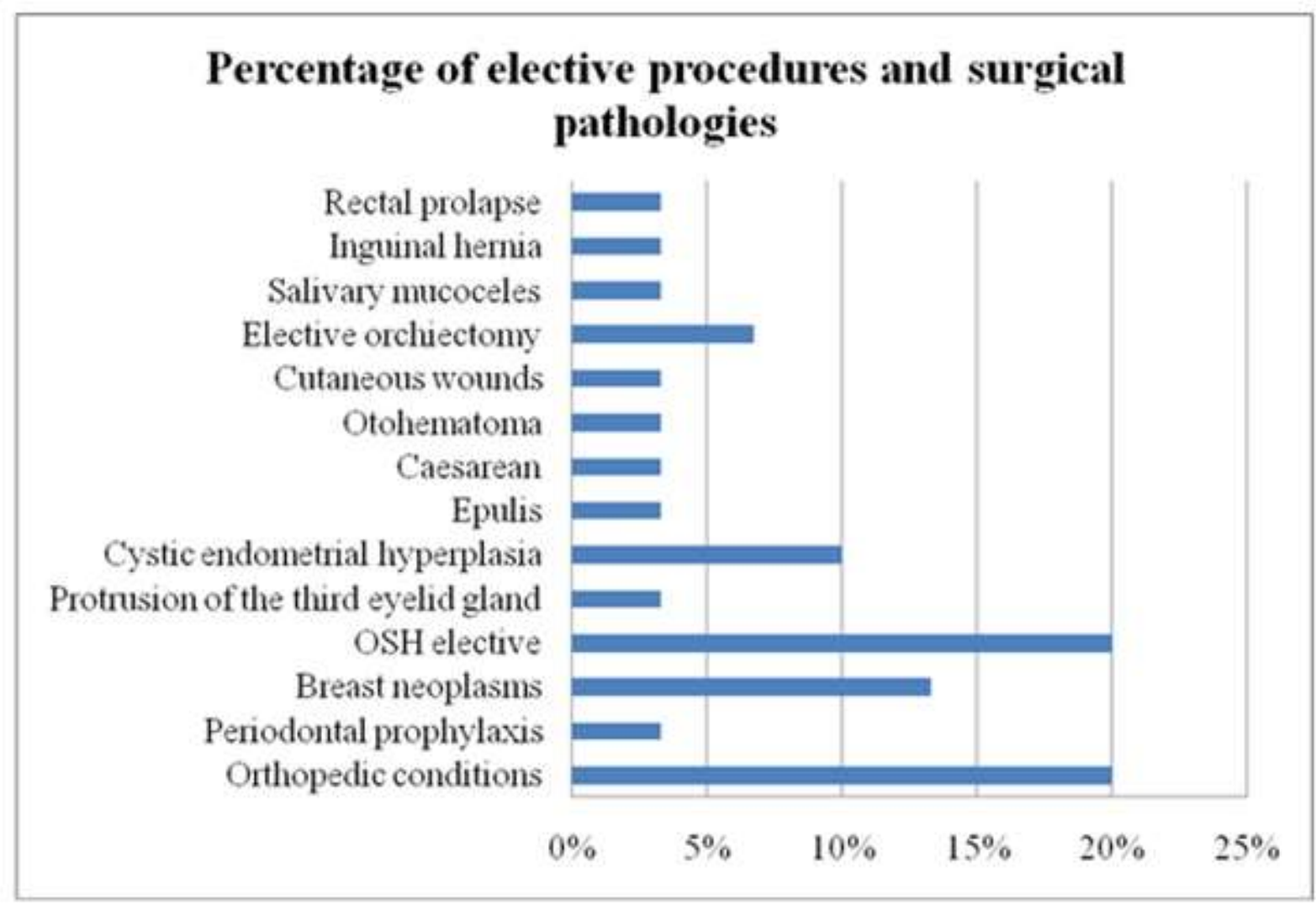

Source: The authors (2017).

Figure 6. Elective procedures and surgical conditions corresponding to patients evaluated by electrocardiogram in the preoperative period $(n=60)$ in the surgery sector of the Veterinary Hospital of PUCPR, campus Toledo.

With regard to the percentage of alterations according to each patient's breed, the descending order regarding the frequency of involvement was as follows: crossbred dogs (43.4\%), Poodle (17.3\%), Border collie (8.6\%), French Bulldog (4.4\%), Cocker Spaniel (4.4\%), Golden Retriever (4.4\%), Lhasa apso (4.4\%), German Shepherd (4.4\%), Pinscher (4\%), and Rottweiler (4.4\%). Figure 7 shows all the breeds submitted to the electrocardiographic evaluation in the present study.

Confronting the percentage between the assessed males and females, a ratio of $63.3 \%$ versus $36.7 \%$ was obtained. From the females evaluated, $21.1 \%$ of animals presented absence of electrocardiographic changes. Among the males submitted to preoperative examination, $36.36 \%$ of the animals had no heart rhythm disturbances.

Based on the concept that the large variation in body shape among the different dogs breeds can alter the acceptable standardized measures ${ }^{(21)}$, we considered weight patterns (up to $9.9 \mathrm{~kg}$, from 10 to 20 $\mathrm{kg}$, and above $20 \mathrm{~kg}$ ) during the interpretation of the electrocardiograms ${ }^{(22)}$ in order to analyze the cardiac electrical activity in a correct and adequate way. Therefore, considering the total population of dogs studied ( $n=60)$, alterations in the electrocardiogram were found in $76.9 \%$ of the animals with 
up to $9.9 \mathrm{~kg}$, in $66.7 \%$ of those weighing from 10 to $20 \mathrm{~kg}$, and in $75 \%$ of those over $20 \mathrm{~kg}$ (Figure $8)$.

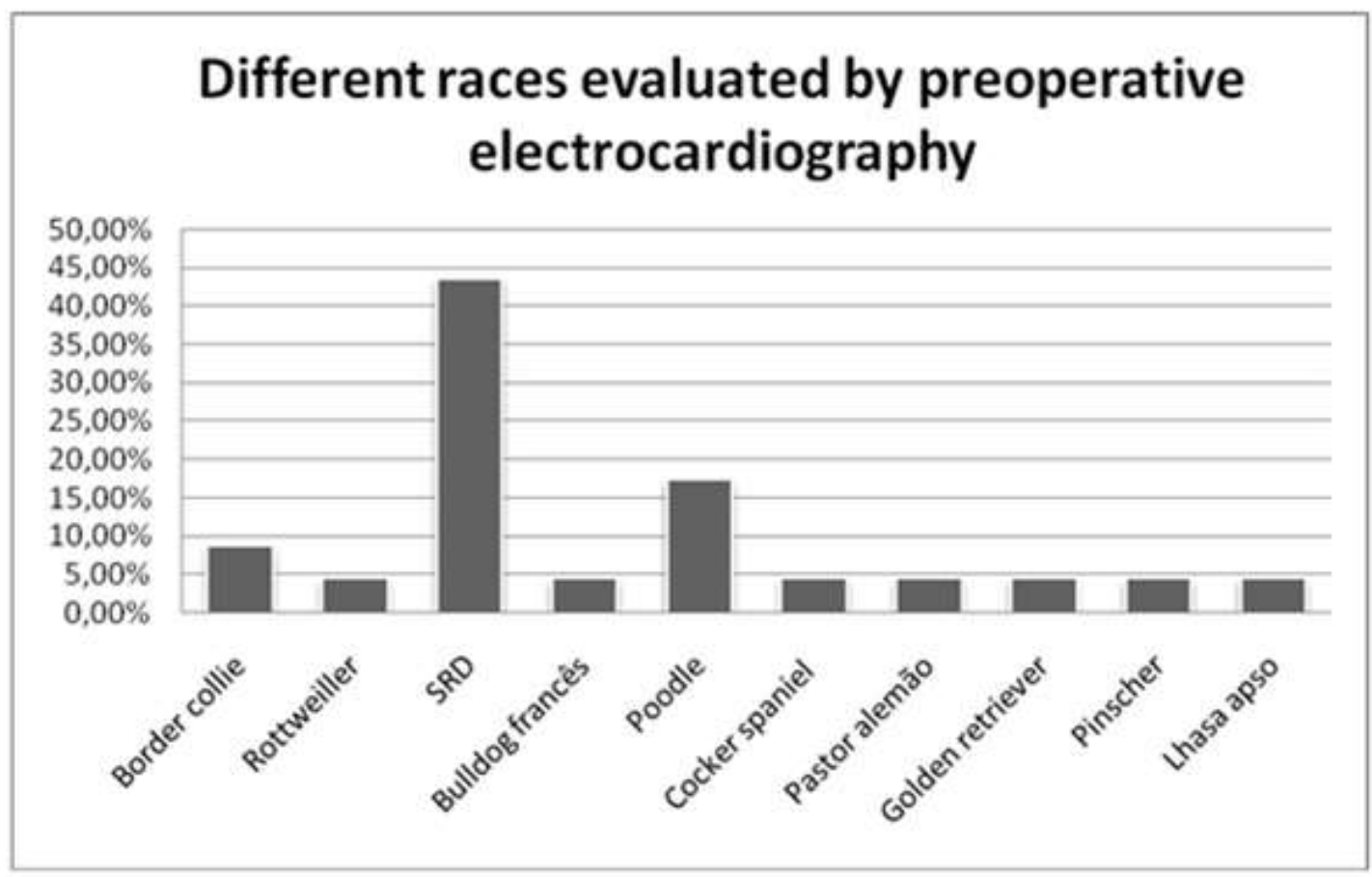

Source: The authors (2017).

Figure 7. Percentage of each breed submitted to preoperative electrocardiographic evaluation in the surgery sector at the Veterinary Hospital of PUCPR, campus Toledo.

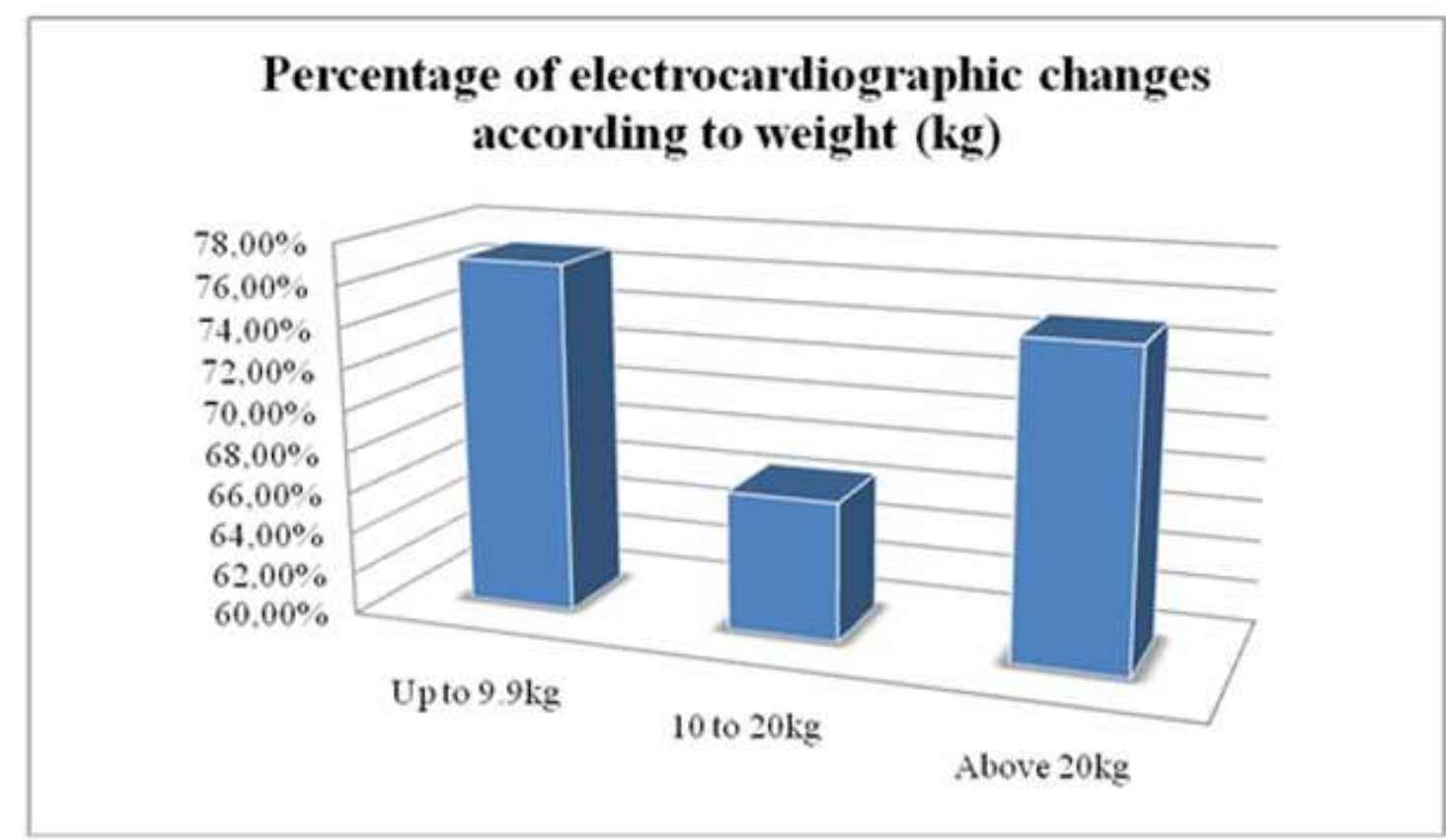

Source: the authors (2017).

Figure 8. Percentage of electrocardiographic changes according to the body weight of each dog evaluated in the preoperative period in the surgery sector of the Veterinary Hospital of PUCPR, campus Toledo. 
According to the age range of the studied dogs, we observed that among the small animals, the electrocardiographic alterations corresponded to a percentage of $7.7 \%$ of puppies, $30.8 \%$ of adults, and $38.46 \%$ of elderly dogs. Among the medium-sized animals, $10 \%$ of the puppies presented alterations in the electrocardiographic tracing, 30\% of adults, and 30\% of the elderly. In the group of large dogs, the same percentage of cardiac rhythm abnormalities was observed among the puppies, adults and the elderly, corresponding to $28.6 \%$ of each age group (Figure 9 ).

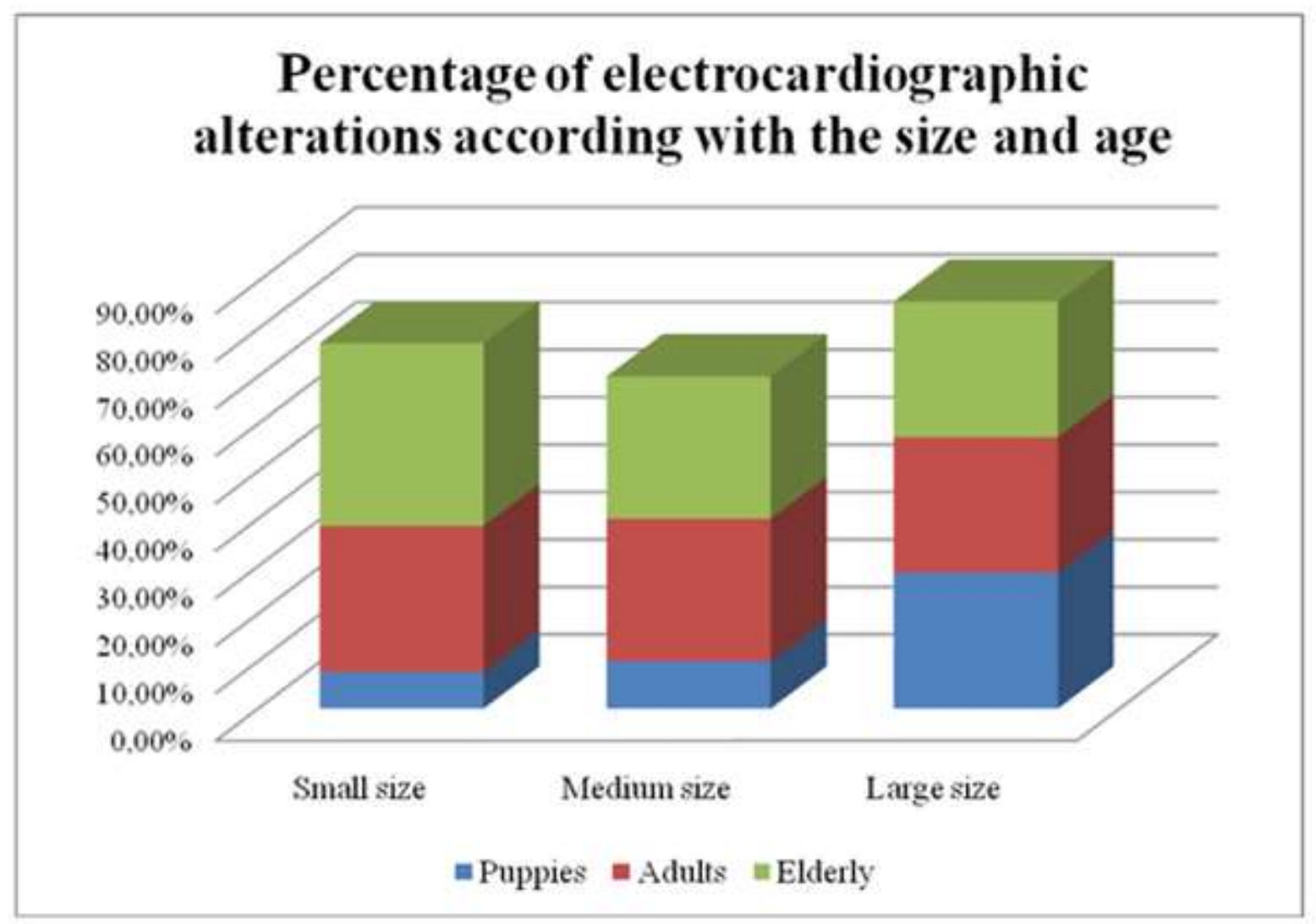

Source: The authors (2017).

Figure 9. Percentage of electrocardiographic changes verified in the preoperative examination of dogs according to size (small, medium and large) and age (puppies, adults and elderly) of each evaluated patient.

\section{Discussion}

In a study carried out by Carvalho et al. ${ }^{(24)}, 46 \%$ of the dogs showed alterations, indicating a high frequency of abnormalities. The percentage verified by Rabelo ${ }^{(7)}$ was even higher $(65 \%)$, corroborating the results found in the present study, where $76.7 \%$ of the dogs presented some type of abnormality in the electrocardiogram.

According to Figure 5, the most frequent electrocardiographic alterations in this study were: respiratory sinus arrhythmia (30\%), atrial fibrillation $(16.7 \%)$, sinus tachycardia $(10 \%)$, increase in $\mathrm{R}$ wave amplitude (10\%), and ST segment depression (10\%). These results agree with those by Rabelo $^{(7)}$ and Carvalho et al. ${ }^{(24)}$ regarding the most observed changes in the preoperative electrocardiographic evaluation. Regarding the disorders found in lower frequencies, we observed: 
first-degree atrioventricular block (6.7\%), increase in P wave amplitude (3.3\%), decrease in R wave amplitude (3.3\%), ST segment elevation (3.3\%), and sinus bradycardia (3.3\%). These alterations may be linked to heart disease, systemic disease or, in some cases, a normal variation ${ }^{(21)}$. It is worth emphasizing that according to Wolf et al. ${ }^{(22)}$, Camacho et al. ${ }^{(25)}$ and Gava et al. ${ }^{(26)}$, the conventional evaluation method used in the present study shows more absolute values when compared to the computerized method, thus guaranteeing more precise results as the electrocardiographic changes of each patient.

Regarding the percentage of alterations according to the breed of each patient, the most frequent was crossbred animals (43.4\%), followed by Poodle (17.3\%) and Border collie (8.6\%), as observed in Figure 7. In a similar study conducted by Carvalho et al. ${ }^{(24)}$, similar results were found, where $48.52 \%$ of the animals that presented alterations had undefined breed (crossbred) and $22.78 \%$ were poodles, representing more than $70 \%$ of the animals evaluated.

According to other studies in veterinary cardiology ${ }^{(21,24-27)}$, males are more likely to develop heart disease, disagreeing with the results found in the present study, where the female population had a higher percentage of electrocardiographic changes than the male one, presenting $78.9 \%$ and $63.64 \%$, respectively. The divergence between the results obtained in this research and those reported in the aforementioned studies may be because the percentage of males $(36.7 \%)$ that were part of this study was lower than that of females $(63.3 \%)$

Considering the different weight standards stipulated in order to analyze the cardiac electrical activity in a correct and adequate way, it can be verified that the dogs of the general population showed electrocardiogram alterations in the frequency of $76.9 \%$ for the animals with up to $9.9 \mathrm{~kg}, 66.7 \%$ for those weighing between 10 to $20 \mathrm{~kg}$, and $75 \%$ for those weighing more than $20 \mathrm{~kg}$ Figure 8 . Carvalho et al. ${ }^{(24)}$ reported in a similar study a frequency of changes corresponding to $45.08 \%$ for animals with up to $9.9 \mathrm{~kg} ; 47.85 \%$ for dogs of 10 to $20 \mathrm{~kg}$, and $45.26 \%$ for those with more than $20 \mathrm{~kg}$. The divergence between the results can be related to the low number of samples studied in this project when compared to the aforementioned research ${ }^{(24)}$.

Based on Figure 9, according to the age group of the studied dogs, it can be observed that among the small animals, the electrocardiographic alterations corresponded to a percentage of $7.7 \%$ of puppies, $30.8 \%$ of adults, and $38.46 \%$ of the elderly dogs. Considering the medium-sized animals, $10 \%$ of the puppies presented alterations in the electrocardiographic tracing, $30 \%$ of adults and $30 \%$ of the elderly animals. When the large dogs were analyzed, the same percentage of cardiac rhythm abnormalities were observed in puppies, adults, and elderly animals, corresponding to $28.6 \%$ of each age group. Through these data, it can be concluded that the size had no influence on the electrocardiographic changes. However, age was influential since adult and elderly dogs presented the highest indexes of alterations when compared to the puppies. The results of this variable (age in relation to size) did not present similarities to the data found by Ramirez et al. ${ }^{(11)}$, who observed that old and small dogs presented the highest occurrences of electrocardiographic alterations.

\section{Conclusion}

The present study allowed us to verify that electrocardiographic changes in the preoperative period are frequent in dogs, regardless of age, breed, size, and sex. Thus, electrocardiography proved to be an auxiliary diagnostic method of great importance in surgical patients, ensuring greater anesthetic safety and lower risk of cardiovascular complications. 


\section{References}

1. Vailati MDCF, Camacho AA, Schwartz DS, Lourenço MLG, Takahira RK, Franco SRVDS. Características eletrocardiográficas de cães da raça boxer. Veterinária e Zootecnia [Internet]. 2009 Dez [cited 2017 Aug 09];16(4):698-707. Disponível em: https://repositorio.unesp.br/handle/11449/140493. Portuguese.

2. Fossum TW. Cirurgia de pequenos animais. 4th ed. Rio de janeiro: Elsevier, 2015. 1619p. Portuguese.

3. Futema F. Avaliação pré-anestésica. In: Fantoni DT, Cortopassi SRG. Anestesia em cães e gatos. 1st ed. São Paulo: Roca, 2002. 389p. Portuguese.

4. Souza FS, Pinotti JRP, Vieira JE, Segurado AVR, Botelho MPF, Mathias LAST. Validade da rotina de realização do eletrocardiograma na avaliação pré-operatória de idosos. Revista Brasileira de Anestesiologia [Internet]. 2005 Jan/Feb [cited 2017 Aug 09];55(1):59-71. Disponível em: http://www.scielo.br/pdf/rba/v55n1/v55n1a07.pdf. Portuguese.

5. Tudury EA, Camacho AA, Lagêdo CMG, Vidal IM. Diagnóstico e tratamento das arritmias de cães e gatos observadas no monitor cardíaco. Revista do Conselho Federal de Medicina Veterinária - Brasília/DF. 2003;30(9)25-38. Portuguese.

6. Paddleford RR. Drogas anestésicas. Manual de anestesia em pequenos animais.2nd ed. São Paulo: Roca, 2001. 423p. Portuguese.

7. Rabelo CR. A importância da avaliação eletrocardiográfica como exame pré-operatório em cães. Boletim Informativo - Anclivepa MG, p. 8, 2004. Portuguese.

8. Anyukhovsky EP, Sosunov EA, Plotnikov A, Gainullin RZ, Jhang JS, Marboe CC, Rosen MR. Cellular electrophysiologic properties of old canine atria provide a substrate for arrhythmogenesis. Cardiovascular Research [Internet]. 2002 May [cited 2017 Aug 09];54(2):462-469. Disponível em: https://academic.oup.com/cardiovascres/article/54/2/462/275838/Cellular-electrophysiologic-properties-ofold. English.

9. Fries CL. Assessment and preparation of the surgical patient. In: Slatter D. Textbook of small animal surgery. 2nd ed. Philadelphia: Elsevier Health Sciences, 2003. 2896p. English.

10. Carr AP, Tilley LP, Miller MS. Tratamento de arritmias cardíacas e distúrbios de condução. In: Tilley LP, Goodwin JK. Manual de Cardiologia para Cães e Gatos.3rd ed. São Paulo: Roca, 2002. 489p. Portuguese.

11. Ramirez EY, Palanca IM, Pablo-Blanco JB, Alonso AM. Arritmias cardíacas no cão e gato. In: Belerenian GC, Mucha CJ, Camacho AA. Afecções Cardiovasculares em Pequenos Animais. 1st ed.São Paulo: Interbook, 2003. 360p. Portuguese.

12. Rogers MC, Tinker JH, Covina BG. Princípios e Prática de Anestesiologia. 1st ed.Rio de Janeiro: Guanabara, 1993. 1927p. Portuguese.

13. Ferreira WL, Aylon EG, Carregaro AB. Ação antiarrítmica do isofluorano em cães submetidos a arritmias ventriculares induzidas por cloreto de bário. Arquivo Brasileiro de Medicina Veterinária e Zootecnia [Internet]. 2006 Dec [cited 2017 Aug 12];58(6):1064-1069. Disponível em: http://www.scielo.br/scielo.php?script=sci_arttext\&pid=S0102-09352006000600014. Portuguese.

14. Abbott JA. Doença valvular adquirida. In: Tilley LP, Goodwin JK. Manual de Cardiologia para Cães e Gatos.3rd ed. São Paulo: Roca, 2002. 489p. Portuguese.

15. Atkins CE. Cardiac manifestations of systemic and metabolic disease. In: Fox PR, Sisson DJ, Moïse SN. Textbook of Canine and feline cardiology: Principles and Clinical Practice. 2nd ed. Philadelphia: Saunders, 1999. 955p. English. 
16. Goodwin JK. Eletrocardiografia. In: Tilley LP, Goodwin JK. Manual de Cardiologia para Cães e Gatos.3st ed. São Paulo: Roca, 2002. 489p. Portuguese.

17. Edwards NJ. Bolton's Handbook of canine and feline elrctrocardiography.2nd ed. Philadelphia: Saunders, 1987. 381p. English.

18. Lunney J, Ettinger S. Arritmias cardíacas. In: Ettinger SJ, Feldman EC. Tratado de medicina interna veterinária. 4th ed. São Paulo: Manole, 1997. 3020p. Portuguese.

19. Brourman JD, Schertel ER, Allen DA, Birchard SJ, Dehoff WD. Factors associated with perioperative mortality in dogs with surgically mananged gastricdilatation-volvulus: 137 cases. Journal of the American Veterinary Medical Association [Internet]. 1996 Jun [cited 2017 Aug 12];208(11):1855-1858. Disponível em: https://www.ncbi.nlm.nih.gov/pubmed/867547. English.

20. Nelson RW, Couto CG. Medicina interna de pequenos animais. 5th ed. Rio de Janeiro:Elsevier, 2015. 1474p. Portuguese.

21. Tilley LP. Essential of Canine and feline electrocardiography: interpretation and treatment.3rd ed. Philadelphia: Lea \& Febiger, 1992. 500p. English.

22. Wolf R, Camacho AA, Souza RAA. Eletrocardiografia computadorizada em cães. Arquivo Brasileiro de Medicina Veterinária e Zootecnia [Internet]. 2000 Dec [cited 2017 Aug 13];52(6):610-615. Disponível em: http://www.scielo.br/scielo.php?script=sci_arttext\&pid=S0102-09352000000600010. Portuguese.

23. Grandjean D, Vaissaire J, Vaissare JP. Enciclopédia do cão - royal canin. 1st ed. Paris: Éditeur Aniwa Puplishing, 2001. 562p. English.

24. Carvalho CF, Tudury EA, Neves IV, Fernandes THT, Gonçalves LP, Salvador RRCL. Eletrocardiografia pré-operatória em 474 cães. Arquivo Brasileiro de Medicina Veterinária e Zootecnia [Internet]. 2009 May [cited 2017 Aug 14];61(3):590-597. Disponível em: http://www.scielo.br/pdf/abmvz/v61n3/11.pdf. Portuguese.

25. Camacho AA, Paulino JD, Pascon JPE, Teixeira AA. Comparison between conventional and computerized electrocardiography in cats. Arquivo Brasileiro de Medicina Veterinária e Zootecnia [Internet]. 2010 Abr [cited 2017 Nov 29];62(3):765-769. Disponível em: http://www.scielo.br/pdf/abmvz/v62n3/38.pdf. English.

26. Gava FN, Paulino-Junior D, Pereira-Neto GB, Pascon JPE, Sousa MG, Chanpion T, Camacho AA. Eletrocardiografia computadorizada em cães da raça Beagle. Arquivo Brasileiro de Medicina Veterinária e Zootecnia [Internet]. 2011 Mar [cited 2017 Nov 29];63(2):317-321. Disponível em: http://www.scielo.br/pdf/abmvz/v63n2/07.pdf. Portuguese.

27. Kelly DF. Interpretação eletrocardiográfica. In: Darke PG, Bonagura JD, Kelly DF. Atlas ilustrado de cardiologia veterinária. 1st ed. São Paulo: Manole, 2000. 186p. Portuguese. 